\title{
THE EFFECTS OF HuMAN RESIDENTIAL DEVELOPMENT ON AVian COMMUNities AlONG THE SNAKE River RIPARIAN CORRIDOR IN JACKSON HOLE, WY
}

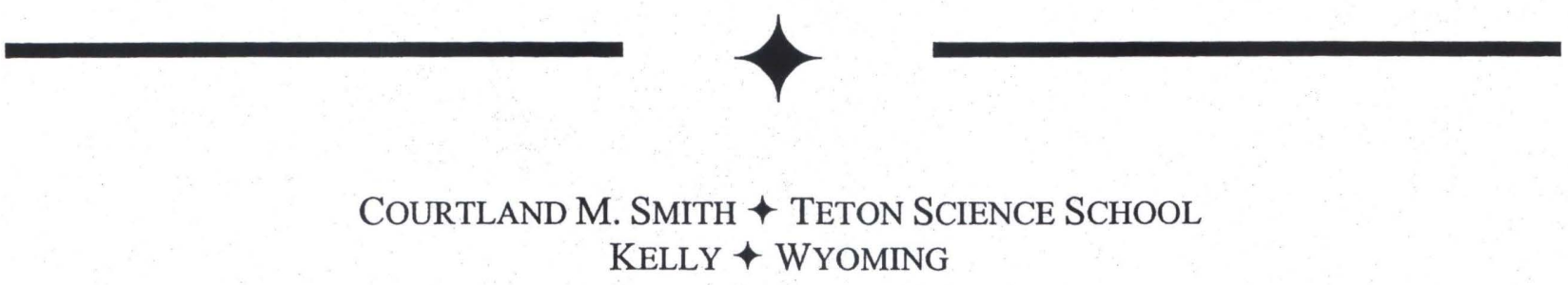

\section{$\uparrow \quad$ ABSTRACT}

Throughout North America, bird declines may be attributable to loss of habitat on the breeding grounds. Human land uses, especially residential development pressures within western ecosystems, are greatly impacting riparian landscapes and biota, particularly breeding birds. While most studies have focused on eastern birds, it is unclear how western bird assemblages respond to development and its concomitant effects on habitat alteration and fragmentation. I sampled bird community parameters and habitat variables at three spatial scales (microhabitat, macrohabitat, and landscape) along a human development gradient along the Snake River riparian corridor in Jackson Hole, WY. Fifty-six cottonwood forest patches were surveyed during the 2001-02 breeding season. Principal component analysis, canonical correspondence analysis, and multiple linear regression statistical tests were used to determine the effects of housing densities on avian assemblages, guilds, and habitat features. Overall species richness and diversity declined with increasing human development. Neotropical migrant species were most negatively impacted and consistently declined in proportional representation on forested plots as human development densities increased. Short-distance migrants, food generalists, ground gleaners, and avian nest predators all increased with increasing human development. Brood parasites, on the other hand, did not increase with increasing fragmentation and their distribution may reflect the availability of nest host species. Of the environmental variables measured, landscape features
\end{abstract}

were most affected and metrics consistent with habitat fragmentation were most correlated with human development. These results suggest that residential development within riparian habitats may be exerting a strong negative influence on western bird communities and at high densities may lead to a depauperate avian biota and reproductive sinks.

\section{$\uparrow \quad$ METHODS OVERVIEW}

\section{Section 2.1: Study Area}

Bird, vegetation, and landscape data were collected in riparian forest patches along the Snake River in Jackson Hole, Wyoming. The study area was approximately $40 \mathrm{~km}$ long from the southern portion of Grand Teton National Park (GTNP) (4839833N, $526157 \mathrm{E}$, Zone $12 \mathrm{~T}$ ) to the town of Wilson, Wyoming (4815635N, 512057E, Zone 12T) in its northern and southern extents, respectively. Surveys were conducted on private land $(n=42)$ located within Teton County and within the boundaries of GTNP $(\mathrm{n}=14)$. Dominant tree species were cottonwood (Populus spp.) and spruce (Picea spp.) with a variable understory. Grasses, forbs, bare ground, and detritus formed the dominant ground cover classifications. Smith (2002) provides a complete overview of the study area as well as additional information on methods, results, analyses, and implications.

I selected a stratified random sample of plots along a human development density gradient based 
on a query of a 1999 high-resolution $\left(0.3 \mathrm{~m}^{2}\right.$ pixel size) digital aerial photograph of Teton County (Horizons, Inc. 1999). ArcView 3.2 (ESRI) was used to digitize the raster data to ensure that all sets met the following criteria: 1) each plot was separated by at least $150 \mathrm{~m}$ to insure independence of bird data, 2) sites were selected in the major categories of riparian forest, cottonwood and spruce, 3) plots were located within patches with an area $>2,500 \mathrm{~m}^{2}$, and 4) had a negligible slope. Sites were visited to ensure accuracy of site-specific attributes.

From the pool of potential survey sites, fourteen plots were randomly selected in each of the low- (Figure 1), medium- (Figure 2), and highdensity (Figure 3) development areas. Landowner permission was obtained to conduct point counts throughout the breeding season. Fourteen reference plots were established in areas with no human development (reference plots) located in the southern portion of GTNP.

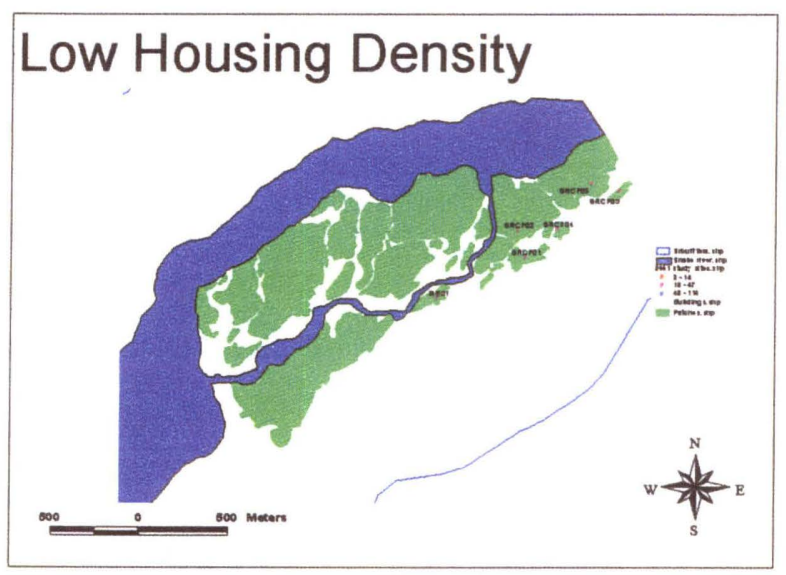

Figure 1: Figure of Low Density Housing

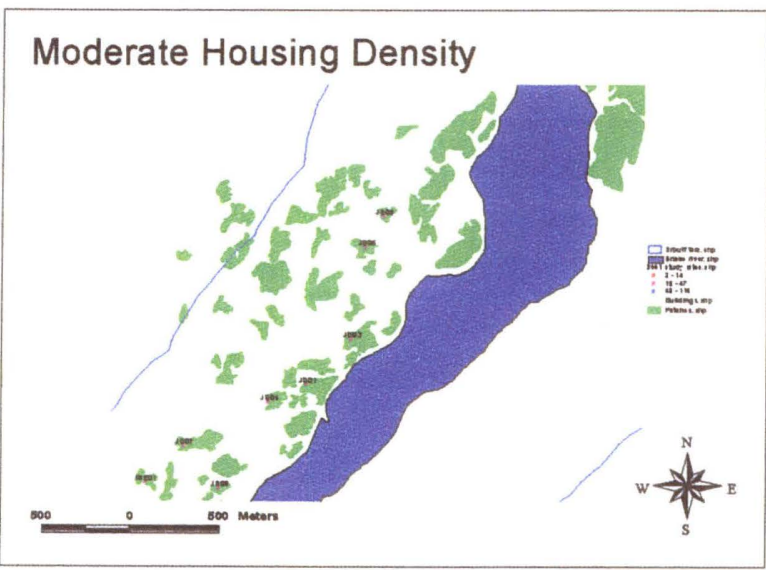

Figure 2: Figure of Moderate Housing Density Sites

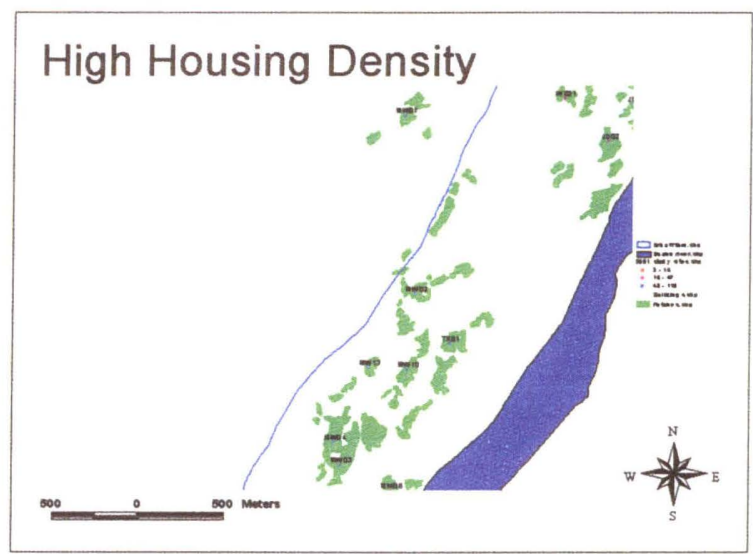

Figure 3: Figure of High Housing Density Sites

\section{Point Count Protocols}

Avian surveys were conducted between May 20 and June 30, 2001 and 2002. Bird abundance and diversity data were collected using the $25 \mathrm{~m}$ fixedradius and unlimited-radius point count described by Hutto et al. (1986). Count duration was 15 minutes long. Point counts were conducted between the hours of 0600 and 1000 . To control for biases associated with varying avian activity levels throughout the survey period, each site was surveyed in the early, mid, and late portions of the morning (0600-0720, 0720-0840, 0840-1000, respectively). Point counts were not conducted during periods of inclement weather (e.g., strong winds, precipitation).

Bird data generated from the observations included species richness, abundance, diversity, and guild composition. The mean number of detections over the three visits was used to calculate relative abundance values. A priori life history guilds, including nesting, migratory, foraging, and food, were classified according to Erlich et al. (1988). Migratory status was determined from previously published data, including Johnsgard (1986), Erlich et al. (1988), Freemark and Collins (1992). Diversity was calculated according to the Shannon's Diversity Index (Zar 1984 and Krebs 1989).

\section{Scale Perspectives}

I selected a nested project design in order to determine the effects of human development on bird habitat use at a variety of spatial scales. Finer resolution of microhabitat provided insight into habitat utilization while coarser metrics (i.e., landscape) placed habitats within a context. Table 1 summarizes all variables measured. 


\section{Microhabitat Sampling}

Vegetation sampling techniques used were those developed by James and Shugart (1970), modified by Noon (1981). Circular plots (0.04ha) were constructed around the point count location and at random points within the forest patch. Large, medium, and small area plots were sampled using three, two, or one plots, respectively, in order to standardize sampling effort. Forest structural components measured were \% canopy and ground cover, understory density, shrub and ground cover dispersion, dbh of all trees $>3 \mathrm{~cm}$ within the plot, representative tree height (five trees), shrub and stem density of coniferous and deciduous shrubs (stem diameter $\leq 3 \mathrm{~cm}$ ), number of snags present, and dominant shrub species (Table 1).

\section{Macrohabitat Metrics}

In addition to the fine grain analysis of habitat, I employed a macrohabitat-level approach. Using Arc View 3.2 GIS (ESRI), digital orthoquads, and aerial photographs of the study area, I incorporated methods described by McGarigal and Marks (1995) to analyze contextual and structural landscape information. These included measuring patch area, perimeter, perimeter:area ratio, and core area (see also Freemark et al. 1995).

\section{Landscape Metrics}

To determine the effects of housing development on landscape-scale features and subsequent alterations within the bird community, several measures were computed. Landscape metrics included number of houses and roads within $500 \mathrm{~m}$, mean distance to the five closest patches (i.e., degree of isolation), mean area of five closest patches, and total area of patches within $500 \mathrm{~m}$ of each patch. Landscape metric values were calculated based on queries and measurements taken from the GIS database.

Landscape coverages were also calculated within $1 \mathrm{~km}^{2}$ of each study plot. Digital aerial photographs of each study site were overlaid with a reference grid at a scale of 1:6,000. Estimates were made for the percentage of land cover in each $200 \mathrm{~m} x$ $200 \mathrm{~m}$ plots $(n=25)$ and averaged across the $1 \mathrm{~km}^{2}$ area. Land coverage classifications included: nonforested habitats (bare ground, gaps in forests, grass, and upland sagebrush habitats), forest coverage, water, wetland shrub (Salix spp.), sand, buildings, and roads (Table 1).

\begin{tabular}{|c|c|c|c|c|c|c|c|}
\hline \multirow{3}{*}{$\begin{array}{l}\text { Table } 1 \\
\text { Num. }\end{array}$} & \multicolumn{4}{|c|}{ : Summary Statistics of Environmental Variables } & \multirow{3}{*}{ Sum } & \multirow{3}{*}{ Minimum } & \multirow{3}{*}{ Maximum } \\
\hline & Variable & Units & Mean & $\begin{array}{l}\text { Standard } \\
\text { Deviation }\end{array}$ & & & \\
\hline & Microhabitat & & & & & & \\
\hline 1 & $\begin{array}{l}\text { Deciduous } \\
\text { Trees }\end{array}$ & $\#$ & 15.58 & 9.024 & 872.5 & 4.333 & 49 \\
\hline 2 & $\begin{array}{l}\text { Coniferous } \\
\text { Trees }\end{array}$ & $\#$ & 3.958 & 4.145 & 221.667 & 0.333 & 20 \\
\hline 3 & Snags & $\#$ & 1.333 & 1.378 & 74.667 & 0 & 8 \\
\hline 4 & Tree Density & $\# / \mathrm{ha}$ & 514.658 & 240.585 & 28820.83 & 200 & 1325 \\
\hline 5 & Mean Tree dbh & $\mathrm{cm}$ & 31.018 & 9.419 & 1737.025 & 8.941 & 64.787 \\
\hline 6 & Canopy Cover & $\%$ & 73.884 & 17.738 & 4137.497 & 12.567 & 93.825 \\
\hline 7 & Canopy Height & ft. & 67.106 & 10.543 & 3757.922 & 44.5 & 90.75 \\
\hline 8 & $\begin{array}{l}\text { Deciduous } \\
\text { Shrubs }\end{array}$ & $\#$ & 54.891 & 49.053 & 3073.875 & 4 & 302 \\
\hline 9 & $\begin{array}{l}\text { Coniferous } \\
\text { Shrubs }\end{array}$ & $\#$ & 11.385 & 16.552 & 637.542 & 0 & 82.333 \\
\hline 10 & $\begin{array}{l}\text { Nearest Log } \\
\text { Distance }\end{array}$ & $\mathrm{m}$ & 7.796 & 2.158 & 436.579 & 2.65 & 11.3 \\
\hline 11 & NL. Diameter & $\mathrm{cm}$ & 18.452 & 9.54 & 1033.287 & 0 & 44 \\
\hline 12 & NL. Length & $\mathrm{m}$ & 6.441 & 3.065 & 360.7 & 0 & 15.3 \\
\hline 13 & $\begin{array}{l}\text { Understory } \\
\text { Dens. }(0-0.3 \mathrm{~m})\end{array}$ & $\%$ & 71.748 & 20.085 & 4017.889 & 10 & 100 \\
\hline 14 & $\begin{array}{l}\text { Understory } \\
\text { Dens. }(0.3-1 \mathrm{~m})\end{array}$ & $\%$ & 45.309 & 21.648 & 2537.285 & 0.714 & 100 \\
\hline 15 & $\begin{array}{l}\text { Understory } \\
\text { Dens. (1-2m) }\end{array}$ & $\%$ & 33.949 & 19.292 & 1901.125 & 0 & 100 \\
\hline 16 & $\begin{array}{l}\text { Understory } \\
\text { Dens. }(2-3 \mathrm{~m})\end{array}$ & $\%$ & 34.622 & 19.569 & 1938.833 & 0 & 100 \\
\hline 17 & $\begin{array}{l}\text { Ground Cover } \\
\text { Grass }\end{array}$ & $\%$ & 23.36 & 14.452 & 1308.137 & 1.05 & 61.15 \\
\hline 18 & GC. Forbs & $\%$ & 10.149 & 6.656 & 568.346 & 0.05 & 29.567 \\
\hline 19 & $\begin{array}{l}\text { GC.Bare } \\
\text { Ground }\end{array}$ & $\%$ & 3.648 & 5.691 & 204.308 & 0 & 30.25 \\
\hline 20 & GC. Shrubs & $\%$ & 7.885 & 6.719 & 441.558 & 0.083 & 29.075 \\
\hline \multirow[t]{2}{*}{21} & GC. Litter & $\%$ & 53.437 & 17.915 & 2992.475 & 17.6 & 92.95 \\
\hline & Macrohabitat & & & & & & \\
\hline 22 & Patch Area & ha & 2.36 & 2.873 & 132.16 & 0.351 & 14.459 \\
\hline 23 & Core Area & ha & 0.337 & 1.127 & 18.88 & 0 & 5.195 \\
\hline 24 & $\begin{array}{l}\text { Patch } \\
\text { Perimeter }\end{array}$ & $\mathrm{m}$ & 702.532 & 421.971 & 39341.81 & 241.626 & 2195.795 \\
\hline \multirow[t]{2}{*}{25} & Perimeter:Area & $\mathrm{m} / \mathrm{ha}$ & 0.042 & 0.013 & 2.336 & 0.013 & 0.074 \\
\hline & Landscape & & & & & & \\
\hline 26 & $\begin{array}{l}\text { Number of } \\
\text { Houses }\end{array}$ & $\#$ & 23.661 & 28.708 & 1325 & 0 & 114 \\
\hline 27 & $\begin{array}{l}\text { Nearest } \\
\text { Neighbor }\end{array}$ & $\mathrm{m}$ & 70.659 & 47.487 & 3956.91 & 10.53 & 221.318 \\
\hline 28 & $\begin{array}{l}\text { Area of } \\
\text { Neighboring } \\
\text { Patches }\end{array}$ & ha & 2.273 & 1.619 & 127.271 & 0.445 & 7.91 \\
\hline 29 & $\begin{array}{l}\text { Total Area of } \\
\text { Surrounding } \\
\text { Patches }\end{array}$ & ha & 42.979 & 27.539 & 2406.801 & 8.928 & 109.206 \\
\hline 30 & $\begin{array}{l}\text { Forest } \\
\text { Coverage }\end{array}$ & $\%$ & 0.299 & 0.154 & 16.727 & 0.109 & 0.732 \\
\hline 31 & $\begin{array}{l}\text { Ground } \\
\text { Coverage }\end{array}$ & $\%$ & 0.416 & 0.14 & 23.284 & 0.114 & 0.645 \\
\hline 32 & $\begin{array}{l}\text { Water } \\
\text { Coverage }\end{array}$ & $\%$ & 0.098 & 0.07 & 5.497 & 0.004 & 0.286 \\
\hline 33 & $\begin{array}{l}\text { House } \\
\text { Coverage }\end{array}$ & $\%$ & 0.016 & 0.017 & 0.903 & 0 & 0.071 \\
\hline 34 & Road Coverage & $\%$ & 0.045 & 0.039 & 2.509 & 0 & 0.129 \\
\hline 35 & Sand Coverage & $\%$ & 0.057 & 0.05 & 3.178 & 0 & 0.183 \\
\hline 36 & $\begin{array}{l}\text { Wetland Shrub } \\
\text { Coverage }\end{array}$ & $\%$ & 0.07 & 0.053 & 3.904 & 0 & 0.236 \\
\hline 37 & $\begin{array}{l}\text { Other } \\
\text { Human } \\
\text { Disturbance }\end{array}$ & \# & 9.679 & 9.522 & 542 & 0 & 29.667 \\
\hline
\end{tabular}

Avian species richness, abundance and diversity were calculated for each site using PC-ORD (McCune and Mefford 1999). Each of the 37 environmental variables measured was tested for normality (i.e., skewness, kurtosis, normal probability plots, and Ryan-Joiner tests for normality) using MINITAB statistical software (MINITAB 1998). Data that exhibited significant departures from 
normality were transformed prior to analysis using standard transformation techniques, including square root, logarithmic, and arcsine square root transformations (Neter et al. 1989).

I used principal component analysis (PCA) to condense the 37 environmental variables to composite values using MINITAB statistical software (MINITAB 1998). Significant components were then used in multiple linear regression analysis (MRA) to determine the effects of the dominant environmental gradients on species richness, abundance, diversity, and migratory status.

I employed Canonical Correspondence Analysis (CCA) to determine the effects of the dominant environmental gradients on individual bird, food, foraging, and nesting guild distributions in environmental space using PC-ORD (McCune and Mefford 1999).

\section{$\uparrow \quad$ RESULTS OVERVIEW}

\section{Bird Occurrence}

During the 2001-02 breeding seasons, over 9,000 individual birds were detected representing 61 species during 336 visits made to the 56 study sites (refer to Smith 2002 for complete species lists). Species richness ranged from 10 to 24 species with a mean of 17 species per plot. Simpson's Diversity for each plot ranged from 2.829 to 1.71 with a mean of 2.429 .

\section{Habitat}

Habitat variables were collected and analyzed at three spatial scales (microhabitat, macrohabitat, and landscape). Sites were dominated by a cottonwood canopy and had variable understory and ground cover. Patches were small with large amounts of edge habitat and limited core area. All patches were surrounded by upland sagebrush habitats or agricultural lands.

Six principal components for the 37 environmental variables were deemed to be meaningful according to the scree criterion and broken-stick eigenvalues (McCune and Mefford 1999; McGarigal et al. 2000). The component loadings were considered to be significant if $>0.450$ (McGarigal et al. 2000) and were examined for relationships among variables. Most components loaded on a set of conceptually related variables and I assigned ecological meaning as appropriate. Of the total variation within the environmental matrix, $67.2 \%$ was captured by the six selected components. Table 2 summarizes the PCA loadings for the 37 environmental variables.

\begin{tabular}{|c|c|c|c|c|c|c|}
\hline \multicolumn{7}{|c|}{ Table 2: Principal Componeen Loedings of 37 Environmental Varisobles } \\
\hline Priadipal Componemat & rCI & NC2 & ma & PCA & PCS & rar \\
\hline Varieblea & 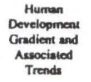 & $\begin{array}{l}\text { Understory Densily } \\
\text { and } \boldsymbol{X} \text { Welland } \\
\text { Vegectation }\end{array}$ & 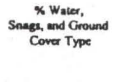 & $\begin{array}{c}\text { Pastch } \\
\text { Characteristicas }\end{array}$ & $\begin{array}{c}\text { Sland Age } \\
\text { and size of } \\
\text { odjecent patcheas }\end{array}$ & $\begin{array}{c}\text { Mof } \\
\text { Conifens }\end{array}$ \\
\hline Elegenvalues & 7.996 & 5.700 & 3.639 & 3.182 & 2.334 & 1.939 \\
\hline XEsplaimed & 21.600 & 15.600 & 9.800 & 8.600 & 6.300 & 5.200 \\
\hline Cumutative $\times$ & 21.600 & 37.200 & 47.000 & 55.600 & 61.900 & 67.200 \\
\hline "Decidenous Treet & .0 .719 & 0.149 & 0.065 & 0.242 & 0.383 & -0.052 \\
\hline "Conilers & 0.394 & 0.385 & -0.071 & 0.133 & 0.137 & -0.495 \\
\hline I SNACS & 0.258 & -0.105 & -0.421 & 0.244 & 0.042 & -0.371 \\
\hline Tree Density & 0.493 & 0.418 & -0.014 & 0.340 & 2459 & -0.335 \\
\hline Tree dab & 0.283 & 0.506 & -0.078 & -0.433 & .0477 & 0.283 \\
\hline Canopy Cover & 0.0305 & 0.125 & 0.326 & -0.292 & 0.255 & 0.229 \\
\hline Casopy Hetemt & 0.100 & 0.314 & -0.326 & 0.513 & -0.176 & 0.205 \\
\hline 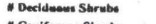 & -0.202 & 20.604 & 0.271 & 0.174 & 0.204 & 0.348 \\
\hline "Coniferous Strrebr & 2.615 & -0.420 & 0.226 & 0.188 & 0.006 & -0.203 \\
\hline Neared Loe Distance & -0.362 & -0.045 & 0.554 & 0.180 & 0.127 & 0.057 \\
\hline Neares Loz Diamenter & 0.081 & 0.321 & 0.167 & -0.194 & -0.133 & 0.165 \\
\hline Neered Log Length & 0.287 & 0.074 & -0.476 & 0.039 & 0.163 & 0.234 \\
\hline $\begin{array}{l}\text { Uadertary Deat (e. } \\
\text { OJm) }\end{array}$ & -0.083 & .0 .729 & -0.298 & 0.030 & 0.033 & 0.306 \\
\hline $\begin{array}{l}\text { Uadersory Deace. (0.3. } \\
\text { Im) }\end{array}$ & -0.282 & $=0.746$ & 0.209 & -0.058 & -0.096 & 0.350 \\
\hline Understory Deme (1-2m) & -0.255 & .0 .630 & 0.444 & 0.147 & -0.176 & 0.145 \\
\hline Uaderriery Desan (2-3m) & -0.263 & 0.565 & 0.463 & 0.182 & -0.159 & 0.123 \\
\hline Ground Cover Grases & -0.112 & -0.275 & .0 .569 & -0.440 & -0.065 & -0.308 \\
\hline GC. Forbs & -0.003 & $=0.578$ & -0.548 & -0.070 & -0.202 & 0.092 \\
\hline GC. Bare Ground & -0.022 & 0.075 & 2.453 & 0.123 & -0.180 & 0.384 \\
\hline GC. Shrube & -0.108 & 0.526 & 0.502 & 0.129 & 0.027 & 0.352 \\
\hline GC. Lieter & 0.250 & 0.542 & 0.353 & 0.336 & 0.206 & 0.171 \\
\hline Hessing Deasiby & 26688 & -0.202 & 0.183 & -0.408 & -0.067 & 0.186 \\
\hline C. Dtat & 2.085 & -0.233 & -0.018 & 0.314 & 0.070 & 0.009 \\
\hline Core Ares & 2.537 & -0.164 & 0.094 & -0.414 & 0.392 & 0.017 \\
\hline Aree & 2.632 & -0.262 & 0.103 & e.554 & 0.379 & -0.041 \\
\hline Perimeter & 2.568 & -0.285 & 0.117 & 0.549 & 0.331 & -0.023 \\
\hline Perimeter:Area & 0.678 & 0.180 & -0.040 & 2480 & -0.301 & 0.168 \\
\hline Nearreat Nefghtbor Diac. & 0.630 & 0.373 & -0.187 & 0.221 & -0.081 & -0.096 \\
\hline N. N. Ares & 0.504 & -0.297 & 0.063 & 0.186 & 0.558 & 0.284 \\
\hline Tousal ares: & 0.704 & -0.441 & 0.295 & 0.061 & -0.144 & 0.105 \\
\hline \% Poreat & 0.609 & -0.443 & 0.372 & 0.115 & -0.236 & 0.049 \\
\hline$\%$ Growad & e.s94 & 0.142 & 0.120 & 0.260 & -0.224 & -0.234 \\
\hline \%water & 0.169 & 0.188 & -0.640 & 0.273 & 0.444 & 0.169 , \\
\hline \% Housed & -0.750 & -0.075 & 0.049 & -0.385 & 0.031 & -0.202 \\
\hline X Roada & 8.830 & -0.221 & 0.038 & 0.310 & 0.172 & -0.020 \\
\hline Yasend & 2.554 & 0.113 & -0.399 & 0.295 & 0.253 & 0.216 \\
\hline \%Wetlend & -0.056 & 0.747 & -0.229 & 0.085 & 0.318 & 0.151 \\
\hline
\end{tabular}

The dominant primary component described a decreasing human development gradient. Plots positively associated with this component were larger in size, occurred in closer proximity to neighboring patches, and had significantly fewer roads, houses, deciduous trees, and human disturbance scores. The second component primarily loaded on understory density and $\%$ of wetland shrub within the landscape matrix. Plots with positive associations with this component had dense understories and large amount of wetland shrubs within $1 \mathrm{~km}^{2}$. The third component described $\%$ of water within the landscape matrix and dominant ground cover type. Positively associated plots had more snags, more dispersed downed logs, more ground cover dominated by shrubs and bare ground with less grass cover, while having less water in the landscape matrix. The fourth component captured patch (macrohabitat) characteristics. Patches that were positively associated with this component were larger with a lower perimeter:area ratio. Tree density, mean $\mathrm{dbh}$, and area covered by adjacent patches loaded the fifth component. The abundance of conifers loaded the final component. Plots associated with the fifth component had more trees with smaller mean dbh and were located next to larger patches. 
The increased tree density and smaller $\mathrm{dbh}$ is indicative of younger stands, therefore it was described as an indicator of stand age (i.e., positively associated plots were younger and located closely to larger forest patches). Plots positively related to the final component were characterized by fewer coniferous trees.

\section{Bird-Habitat Relationships}

Avian Species Richness, Diversity, and Abundance

Based on multiple linear regression analysis (MRA), 2 components were significantly related to trends in species richness $\left(r^{2}=0.458, F=6.90\right.$, $\mathrm{P}=0.0001$ ). The best predictors for species richness were principal components 1 (human development) $(\mathrm{t}=5.89, \mathrm{P}=0.0001)$ and $5(\mathrm{t}=-2.08, \mathrm{P}=0.043)$ (stand age and proximity to larger patches).

MRA was used to determine bird diversity response to the environmental matrix. Two principal components were significantly related to trends in avian diversity along the development gradient $\left(\mathrm{r}^{2}=0.497, \quad \mathrm{~F}=8.06, \quad \mathrm{P}=0.0001\right)$. PC1 (human development) was the most significant predictor $(\mathrm{t}=6.13, \quad \mathrm{P}=0.0001)$ and $\mathrm{PC} 2$ (understory characteristics and \% wetland shrubs in the landscape) was the second best predictor of avian diversity along the development gradient $(t=-2.63$, $\mathrm{P}=0.012$ ). MRA showed that bird abundance was not significantly related to any of the principal components $\left(\mathrm{r}^{2}=0.13, \mathrm{~F}=1.22, \mathrm{P}=0.313\right)$.

\section{Individual Species Responses}

Canonical Correspondence Analysis (CCA) was used to determine how bird distributions were structured relative to the measured environmental variables. Bird species associated with human development included Black-billed Magpie, European Starling, Brewer's Blackbird, Northern Oriole, and Common Grackle (Figure 4). Species negatively associated with human development included Dusky Flycatcher, Hammond's Flycatcher, Ruffed Grouse, Dark-eyed Junco, and Swainson's Thrush.

\section{Food Guild Responses}

CCA was used to determine how food guilds were structured according to the environmental variables. Axis 1 described the human development gradient with human-associated guilds located on the left side of the axis and less human tolerant species on the right side. Generalists were negatively associated with Axis 1 (i.e., more abundant in areas of high development). Axis 2 defined a gradient characterized by positive associations with coniferous trees and shrubs and negatively associated with nearest neighbor distance. Plots and guilds associated with this axis were less isolated from neighboring patches and contained more coniferous trees and shrubs. Seedeaters were positively associated with Axis 2 while nectivores were negatively correlated to the axis. Berry eaters and insectivores did not correlate to any of the first 3 axes, indicating they are not significantly structured by either of these gradients.

\section{Foraging Guild Responses}

CCA was also used to determine how foraging guilds were structured according to trends within the environmental variables. Axis I described the human development gradient (i.e., more developed sites occurred along the right side of Axis 1). Environmental variables shown had $r^{2}>0.10$. Axis 3 described forest structural elements, particularly mean tree dbh and downed log characteristics. Foraging guilds associated with human development (i.e., values on the right side of Axis I) included aerial and ground gleaners. Guilds negatively associated with human development were foliage gleaners and hawkers. The bark gleaning guild was associated with Axis 3 and related to patches with larger mean tree $\mathrm{dbh}$ and with longer fallen logs.

\section{Nesting Guild Responses}

CCA revealed how nesting guilds were structured according to the dominant environmental variables. Axis 1 described the human development gradient with human dominated sites and humanassociated species occurring to the left along Axis 1 . Nesting guilds associated with development were sphere and cavity nesters while open cup nesters were negatively associated with this gradient (i.e., occurring on the right side of Axis 1). Axis 2 described trends in the number of coniferous trees and nearest neighbor distances (i.e., less isolated patches with more coniferous trees). Pendant and saucer nesters were positively associated with Axis 2 while brood parasites and cup nesters were not as strongly structured by either axis.

\section{Migratory Guild Response}

CCA could not be conducted on migratory guild responses to environmental variables due to 
Axis $3=$ Fragmentation and Human Development

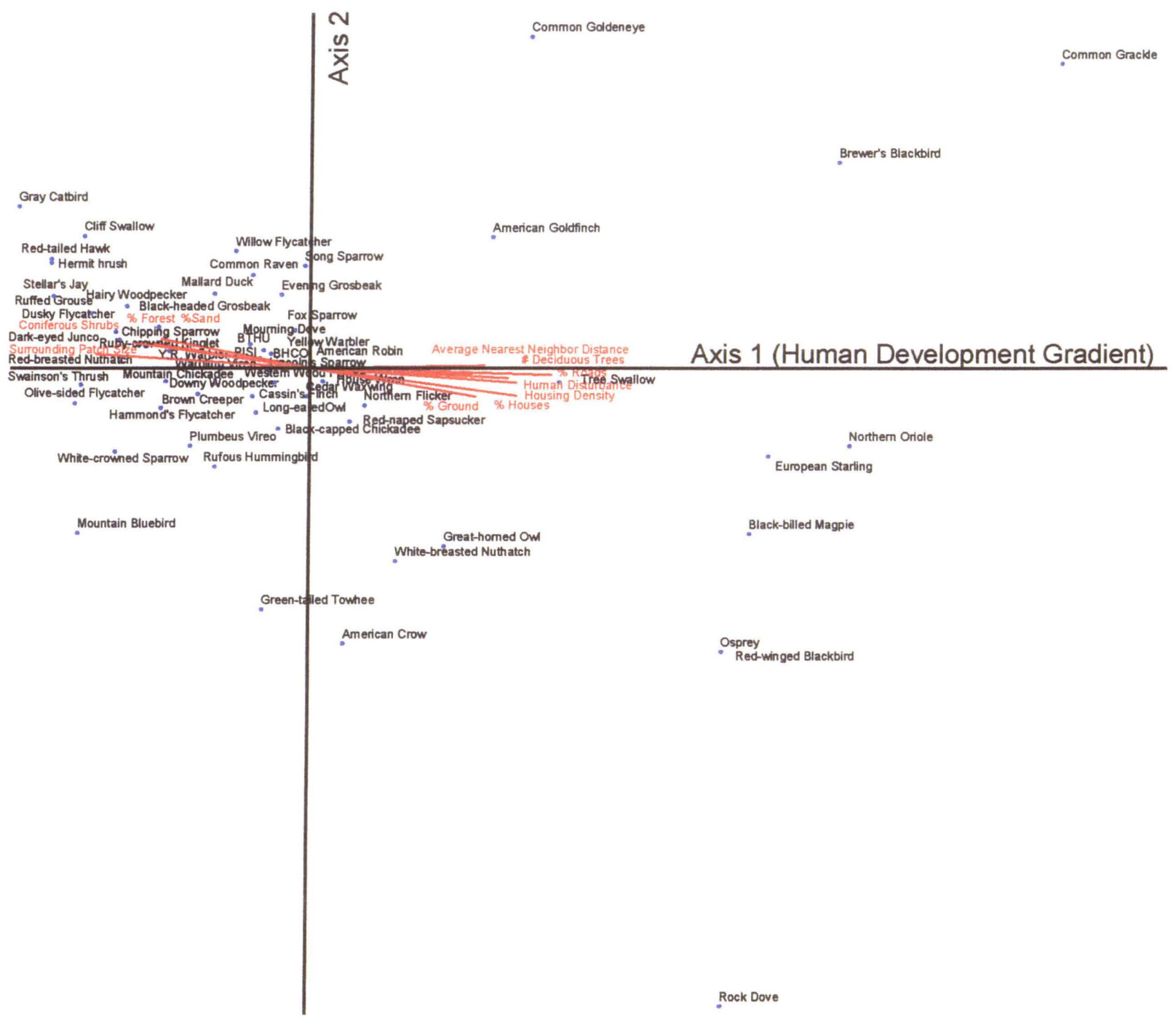

Figure 4: CCA biplot of Individual Species and Environmental Gradients

high levels of multicollinearity. Therefore MRA was employed to determine if migratory strategy was related to the principal components generated from the environmental matrix.

Neotropical migrants were significantly related to $\mathrm{PC} 1$ and $\mathrm{PC} 4 \quad\left(\mathrm{r}^{2}=0.539, \mathrm{~F}=9.55\right.$, $\mathrm{P}=0.0001$ ). $\mathrm{PC} 1$ (human development gradient) was the strongest predictor $(\mathrm{t}=5.85, \mathrm{P}=0.0001)$ and $\mathrm{PC} 4$ (patch characteristics) was the second best predictor $(\mathrm{t}=4.53, \mathrm{P}=0.0001)$. These scores indicate that

Neotropical migrants were more abundant on larger patches with fewer anthropogenic elements in the landscape. Short-distance migrants were negatively related to $\mathrm{PCl}$ (human development gradient; $\mathrm{r}^{2}=0.337, \quad \mathrm{~F}=4.15, \mathrm{P}=0.002 ; \mathrm{t}=-4.67, \mathrm{P}=0.0001$ ). Short-distance migrants were more abundant on 
disturbed sites than on areas with little or no human disturbance. Resident species were not significantly related to any of the principal components $\left(\mathrm{r}^{2}=0.157\right.$, $\mathrm{F}=1.52, \mathrm{P}=0.191)$.

\section{DISCUSSION AND CONSERVATION IMPLICATIONS}

As development and habitat fragmentation increased, local bird communities were significantly impacted. The primary effects of residential development on bird community structure occurred at the landscape scale and included fragmentation effects such as increased patch isolation, smaller forest patches, as well as alterations within the habitat matrix (i.e., forests were surrounded by more roads, houses, and had higher human disturbance scores). Saab (1999) found similar results along the Snake River in Idaho. Shifts within the bird community included decreased species richness and diversity, a trend documented by others (Clergeau et al. 1998; Fernández-Juricic 2000; Jokimäki 1999). Bird abundance was not affected, however this is often the case. Aldrich and Coffin (1980) and Blair (1996) both reported increases in avian abundances as housing densities increased, primarily due to the addition of edge-tolerant and edge-specialist species. I discovered a similar trend along the development gradient in Jackson Hole. The decrease in avian diversity showed that while abundances remained comparable in high-density development, the most dominant species were locally common generalists or ground gleaners, which represent a drastically different community (i.e., lower species richness, diversity, and guild dominance) than those found in undeveloped areas.

I found increases in generalists, shortdistance migrants, ground gleaners, aerial foragers, and cavity and sphere nesters as development increased. Guilds negatively associated with development included foliage gleaners, hawkers, open-cupped nesters, and Neotropical migrants. Given the decline of Neotropical migrant species (Robbins et al. 1989), increasing human development could have serious repercussions on breeding bird habitat conservation in the western United States.

The trends in abundances of brood parasites and avian predators reveal interesting patterns within western bird assemblages along the development gradient. As human densities increased, bird predators, particularly Black-billed Magpies, dramatically increased. This phenomenon has been documented by several other researchers (Tomialojć 1978; Andrén 1992; Nilon et al. 1995; Kluza et al. 2000). While I did not directly measure the impact Black-billed Magpies had on bird nesting success, fledging rates, or overall survivorship, it is likely the presence of these important nest predators exerts a negative pressure on heterospecifics. I am currently investigating the effects of development and associated increases in avian nest predators on nest productivity through an artificial nest study.

Brood parasites such as the Brown-headed Cowbird did not increase with increasing housing densities or habitat fragmentation, which contrasts with results of similar studies in the eastern United States. Simple linear regression analysis indicated a significant relationship between the abundances of cowbirds and Yellow Warblers $\left(\mathrm{P}=.0091, \mathrm{r}^{2}=.119\right)$, the primary nest host species in this study area (Erlich et al. 1986). CCA analysis of individual species distribution in environmental space also indicated a close relationship between Yellow Warbler and cowbird distributions (Fig. 4). This trend in cowbird distributions could be due to fragmentation effects operating in opposite directions within western ecosystems. As fragmentation levels increase, cowbird host species (particularly open cup nesting Neotropical migrants) become less represented within the bird communities. Fragmentation and edge availability is a common feature of western riparian corridors (Knight 1994) and it is likely that cowbirds are able to parasitize a large proportion of undeveloped forest patches. Within the west, brood parasitism is not likely to heavily affect bird populations as human development increases and cowbird distributions may be structured by availability of host species rather than increasing fragmentation.

Conservation efforts in the west should therefore focus on maintaining adequate areas of undeveloped riparian forest tracts. Retaining landscape and macrohabitat (i.e., patch) level characteristics such as large areas of forest, high contagion, and core area could help retain local bird populations. Furthermore, reducing both primary (i.e., disturbance levels) and secondary human impacts (e.g., road and housing densities) may also contribute to conservation efforts. It is clear from the results of my study that increasing housing densities may support more generalist species and avian predators, particularly Black-billed Magpies. It may be that the presence and increased abundance of these species may be even more impactful than the results of this study indicate. Hansen and Rotella (2000) have suggested that cottonwood patches immersed 
within a human-dominated landscape may be acting as reproductive sink areas and may thus be exerting considerably more negative influence on the larger metapopulation than indicated by simple declines in species richness, diversity, and underepresentation of certain assemblage guilds. Despite the attractiveness of the areas for residential development (Hansen and Rotella 1999), it will be vital to limit development in riparian forests to low to moderate densities to ensure the persistence of breeding Neotropical migrant species.

\section{Literature Cited}

Aldrich, J.W. and R.W. Coffin. 1980. Breeding bird populations from forest to suburbia after thirty-seven years. American Birds 34(1): 37.

Andrén, H. 1992. Corvid density and nest predation in relation to forest fragmentation: a landscape perspective. Ecology: 73(3): 794804.

Blair, R.B. 1996. Land use and avian species along an urban gradient. Ecological Applications 6(2): 506-519.

Clergeau, P. J.L. Savard, G. Mennechez, and G. Falardeau. 1998. Bird abundance and diversity along an urban-rural gradient: a comparative study between two cities on different continents. Condor 100(3): 413425 .

Erlich, P.R, D.S. Dobkin, and D. Wheye. 1988. The Birder's Handbook: a field guide to the natural history of North American birds. New York, NY: Simon and Schuster, Inc. $785 \mathrm{p}$.

ESRI. Environmental Systems Research Institute, Inc. ArcView 3.2 GIS application.

Fernàndez-Juricic, E. 2000. Avifaunal use of wooded streets in an urban landscape. Conservation Biology 14(2): 513-521.

Freemark, K.E. and B. Collins. 1992. Landscape ecology of breeding birds in temperate forest fragments. 443-454. In: Martin, T. E. and D. Finch, editors. Ecology and management of migratory birds: A synthesis and r eview of critical issues. Oxford: Oxford University Press. p. 381-427.
Freemark, K. E., J.B. Dunning, S.J. Hejl, and J.R. Probst. 1995. A landscape ecology perspective for research, conservation, and management. In: Martin, T. E. and D. Finch, editors. Ecology and management of migratory birds: A synthesis and r eview of critical issues. Oxford: Oxford University Press. p. 381-427.

Hansen, A.J. and J.R. Rotella. 1999. Abiotic Factors. In: M. Hunter, ed. Maintaining biodiversity in forest ecosystems. Cambridge, UK: Cambridge University Press.

Hansen, A.J. and J.J. Rotella. 2000. Bird responses to forest fragmentation. In: R.L. Knight, F.W. Smith, S.W. Buskirk, W.H. Romme, and W.L. Baker, eds. Forest fragmentation in the Southern Rocky Mountains. Boulder, CO: University of Colorado Press. p. 202-221.

Horizons, Inc. 1999. Digital aerial photograph of Teton County, WY. Rapid City, SD.

Hutto, R.L., S.M. Pletschet, and P. Hendricks. 1986. A fixed-radius point count method for nonbreeding and breeding season use. Auk 103: 593-602.

James, F.C. and H.H. Shugart. 1970. A quantitative method of habitat description. Audubon Field Notes 24: 727-736.

Jokimäki, J. 1999. Occurrence of breeding bird species in urban parks: effects of park structure and broad-scale variables. Urban Ecosystems 3: 21-34.

Johnsgard, P.A, 1986. Birds of the Rocky Mountains: with particular reference to National Parks in the Northern Rocky Mountain Region. Boulder, CO: Colorado Associated University Press. 504 p.

Knight, D. 1994. Mountains and plains: the ecology of Wyoming landscapes. 1st edition. New Haven, CT: Yale University Press. 338p.

Kluza, D.A., C.R. Griffin, and R.M. DeGraaf. 2000. Housing developments in rural New England: effects on forest birds. Animal Conservation 3:15-26.

Krebs, C.J. 1989. Ecological methodology. New York, New York: Harper Collins Publishers, Inc. $654 \mathrm{p}$. 
McCune, B. and M.J. Mefford. 1999. PC-ORD. Multivariate Analysis of Ecological Data, Version 4. MJM Software Design, Glenden Beach, OR, USA.

McGarigal, K. and B.J. Marks. 1995. FRAGSTATS: spatial pattern analysis program for quantifying landscape structure. USDA Forest Ser. Gen. Tech. Rep., Pacific Northwest Res. Sta., Corvallis, OR.

McGarigal, K., S. Cushman, and S. Stafford. 2000. Multivariate statistics for wildlife ecology research. New York, NY: Springer-Verlag New York, Inc. 283 pgs.

MINITAB 1998. MINITAB Inc. Version 12.21 for Windows.

Neter, J., W. Wasserman, M.H. Kutner. 1989. Applied linear regression models, $2^{\text {nd }}$ ed. Burr Ridge, IL: Richard D. Irwin, Inc. 667 pgs.

Nilon, C.H., C.N. Long, and W.C. Zipperer. 1995. Effects of wildland development on forest bird communities. Landscape and Urban Planning 32: 81-92.

Noon, B.R. 1981. Techniques for sampling avian habitats. In: D. Capen, editor. The use of multivariate statistics in studies of wildlife habitat. USDA Forest Service Gen. Tech. Rep. RM-87, Rocky Mountain Forest and Range Experiment Station, Fort Collins. CO. pg. 42-52.
Robbins, C.S., J.R. Sauer, R. Greenberg, and S. Droege. 1989. Population declines in North American birds that migrate to the Neotropics. Proceedings of the National Academy of Science USA 86: 7685-7662.

Robinson, S.K., S.I. Rothsen, M. C. Brittingham, L.J. Petit, and J.A. Grzbowski. 1995. Ecology and behavior of Cowbirds and their impact on host population. In: Martin, T. E. and D. Finch, editors. Ecology and management of migratory b irds: A synthesis and review of critical issues. Oxford: Oxford University Press. p. 428-460.

Saab, V. 1999. Importance of spatial scale to habitat use by breeding birds in riparian forests: a hierarchical analysis. Ecological Applications 91(1): 135-151.

Smith, C. M. 2002. The effects of human residential development on avian communities along the Snake River in Jackson Hole, WY, USA. M.A. thesis. Prescott College, Prescott, AZ.

Tomialojć, L. 1978. The influence of predators on breeding Woodpigeons in London parks. Bird Study 25:2-10.

Zar, J.H. 1984. Biostatistical Analysis, $2^{\text {nd }}$ edition. Englewood Cliffs, NJ: Prentice-Hall, Inc. $718 \mathrm{p}$. 